\title{
Students Giving Students Advice Before The First Day
}

Amy D. DeLine, Central Michigan University

Joseph E. Finck, Central Michigan University

\begin{abstract}
During the last week of class students write advice to the incoming class. This is distributed to incoming students and is more reliable and relevant than that available on RateMyProfessors.com.
\end{abstract}

\section{INTRODUCTION}

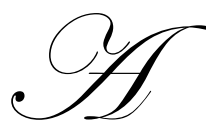

timid freshman walks into his first class and fumbles with his course schedule to see if he's in the right room. He sits down with just a pen in hand and looks over his shoulder at a sophomore who is meeting with some old friends. She appears confident about the course ahead and he catches her conversation. She mentions that she has heard about this professor and that she's ready for the challenges the professor is going to throw at them. The freshman turns back around even more fearful of the required course he already was dreading.

Standing alone in the front of the class stands the professor clutching copies of the course syllabus. Like the students sitting in front of her, she might be anxious or confident. Her goal on this first day is to introduce the course and herself to the students. This is her first chance to address pre- and misconceptions of the course and her as a professor. It is also her opportunity to lay out the expectations she has for her students. Getting the students to understand and accept these expectations is a challenge for even the most experienced college teacher.

The freshman is terrified because he does not know what to expect from this teacher, this course, or any college class. The sophomore appears confident because she has read a few on-line postings about this professor and her friend took a different class from this same professor and relayed her experience. What neither student realizes is that first day uncertainties has the adrenaline flowing in the professor. "Meeting a group of strangers who will affect your well being, is at the same time exciting and anxiety producing for both students and teacher (McKeachie and Gibbs 2001)."

Research on the first day of class by Knefelkamp (Rubin, 1985) showed there was a real desire on the part of both students and teachers for connectedness, but neither group realized the other shared that desire.

If the participants on both sides don't understand how to develop their relationships, learning will be diminished. If you have experienced some anxiety about this meeting, planning some specific steps can not only reduce that feeling, but can get students to share in the sense of purpose you hold for the class.

This paper presents a way to address, before the first day of class, the desire of students to learn about a class and instructor, and the need of faculty to let the students know what the expectations are for his or her class. The paper will show how students, who have taken one or two semesters of a class from a professor, can give advice to the following class. This student-to-student guidance can be easily distributed using classroom management programs, such as BlackBoard.com ${ }^{\mathrm{TM}}$. This new practice will be compared to institutionally administered teacher evaluations and popular student websites, such as RateMyProfessors.com ${ }^{\mathrm{TM}}$. 


\section{IMPORTANCE OF LETTING STUDENTS KNOW WHAT TO EXPECT}

When students come into a class the first thing they need to know is whether or not they are in the right place. This can be verified if the students simply look carefully at their schedule, and may be checked when they receive the syllabus at the beginning of their first class. Once that is established, the students must know whether they have the correct prerequisites for the course. If they do not have the necessary preparation and have somehow enrolled in the course, then the class will be much more difficult for them. Hopefully, the students received appropriate advising before entering the class. If not, the syllabus should tip them off that they are in the wrong course.

Another primary concern to students is the difficulty level of the course. Usually there are a vast range of student expectations. These varying expectations are a function of previous academic achievement, family socioeconomic and educational backgrounds, previous educational opportunities, and exposure to information regarding college (Miller, 2005b). Their expectations in how difficult the course is will affect how confident in they are in the subject matter. Their confidence level, in turn, is critical to persevere with the task at hand (Miller, 2005a), which in this case is being successful in the college classroom.

It is also important for students to know how much work will be expected of them. Some students walk in the first day overconfident of their abilities and underestimate the difficulty of the course and the required demand on their time. Other students are afraid of the material and the professor even a semester before class starts. It can be problematic when students come into a course expecting that it will be a breeze when in reality they have a lot more work to put into it than they presume. On the other hand, when students come in and feel that they will be overwhelmed by the course it can be just as difficult of an experience. Their expectations for success are low and in turn may affect their performance.

The important task for the instructor is to communicate expectations to the students (Eberly et al., 2001). These expectations must be realistic (Davis, 2006) and understandable to the students (Boice, 2000 and Felder et al., 2007). Also, it is crucial that this be communicated with immediacy (Boice, 2000). Finally, the instructor should give the students advice and encouragement for success, and let them know how well their peers have done during previous years in this same course (Davis, 2006).

\section{USE OF THE TRADITIONAL SYLLABUS}

The first day of class is the typical time for a professor to lay out what students can expect while taking the course. According to McKeachie, the basic questions students have about the instructor are: "Are you rigid?" "Will you really try to help students?" "Are you easily rattled?" and "Are you a person as well as a teacher?" (McKeachie, 2006).

To guide students in knowing what the following semester will be like, the instructor can tell the students what the course includes and can also go through a syllabus containing this information. In the past this was usually done on the first day of class. However, now it is now possible, through BlackBoard ${ }^{\mathrm{TM}}$ and similar classroom management programs, to send the syllabus to the students before the course begins. Also, some professors require students to purchase a course pack from the bookstore, which typically will contain the syllabus.

The syllabus is often the initial communication tool that students receive from their professor, as well as being the most formal mechanism for sharing information with the students regarding any course (Dberly et al., 2001). The primary purpose of a syllabus is to communicate to one's students what the course is about, why the course is taught, where it is going, and what will be required of the students for them to complete the course with a passing grade (Altman \& Cashin, 1989). If the syllabus is well-designed, it can go a long way toward clarifying expectations so students have a sense of knowing what they are to do. Professors can let their new students know that they are prepared to help them learn, while also developing the sense of their own responsibility for achieving course goals (Wright, 1989). One way to view the syllabus is as a contract that spells out the professor's expectations for students(Knuther, 2003). 
There is broad agreement on the type of information that should be included in a syllabus (Altman,1989; Birdsall, 1989; Lowther et al., 1989; Wilkerson and McKnight, 1978). The components of a comprehensive course syllabus are frequently discussed at new faculty orientation programs (Zakrajsek, 2007) and have been published in many venues (cf., Davis, 2006).

\section{FACTS, RUMORS AND INNUENDOS ABOUT PROFESSORS AND THEIR COURSES}

Even before the students walk into the classroom, they can discover the reputation of the professor or course from a number of sources. Students who have previously taken the course or professor have always freely relayed their experiences to future students. However, their advice may be skewed since the same professor may use different teaching styles from course to course and may adjust any course from time to time. Also, each student gains a different perspective and will give a future student an opinion biased by their experience, workload and grade. Anecdotally, all educators can point to professors who they admired, while they know some of their peers had unsatisfactory experiences with the same individual. And just as often the reverse was true. Finally, word of mouth information is inherently unreliable because the sample size is usually so small.

The most popular resource now available to students to find information about a future professor and course is a professor evaluation website such as RateMyProfessors.com (RMP) or similar on-line internet sites. The popularity of RMP is undeniable. There have been 5.7 million submissions of 770,000 professors in nearly 6000 schools from the beginning of RMP.com until August 2006 (Otto et al., 2007). Students can quickly go to the website and look up a professor they are considering taking for a class, and discover what other students have said about the professor. "A primary reason for the popularity of online teacher rating sites is, arguably, students' desire for information about classes and professors. Unlike traditional course evaluations where the audience is the teacher and perhaps administrators, the intended audience for RMP and other similar sites is other students (Kindred and Mohammed, 2005).”

Similar to student opinion surveys administered by the institutions, RMP consists of multiple choice options and short written statements. The short answer portion is under "User Comments" and the guidelines instruct the students to "Please keep comments clean. Libelous comments will be deleted," with an additional guidelines link next to it that outlines specific website regulations. Otherwise, students are given free reign to express their opinions about the professor and the course.

The target audience for RMP is other students who could potentially be taking this professor in the future. Students are writing to tell other students what the teacher is like and how difficult the class is. RMP's "About Us" page once stated that it, “...offers a public review (and sometimes a public flogging) of university professors from across the United States and Canada (RateMyProfessors.com, June 2006)."

In focus group studies by Kindred and Mohammed (2005) students showed they were wary of trusting the evaluations at RMP, but continued to use them as a supplement. Clearly, they want as much information about courses and teachers as they can get, even if the source is somewhat questionable. They noted, for example, how conflicting ratings posted to the site diminish credibility. They do, however, appear to be very critical readers of the messages. For example, several students noted that it is easy to tell the "real" comments from the sarcastic or angry ones, so they take the comments many times "with a grain of salt." Students are careful and critical when reading the ratings, because, as one student noted, "You don't exactly know who's writing the responses or why they wrote them."

Kindred and Mohammed also reported that students rely more on the written over the non-written portion of the evaluations. The students basically ignore the numerical ratings, but if they look at any, the easiness score is the one most consulted. The smileys, the students noted, are hard to ignore and are good for creating a first impression of the teacher and the course. For example, if the teacher has many "angry" versus "smiley" faces, this appears to influence their opinion of the teacher initially, but they will investigate further to read the actual written comments. The chili peppers are generally disregarded; students reported that they do not place importance on whether or not a teacher is rated as "sexy." One student summarized this idea by stating, "I think the hot tamale thing 
kind of takes away from the credibility of the site. If you're looking for a professor, obviously their level of attractiveness isn't really a top priority." This appears to be in disagreement with several studies that have shown attractive professors consistently score higher than their less comely colleagues (Felton, 2004; Montell, 2003). However, these two conclusions are not mutually exclusive. It is possible that potential students reading RMP comments are not interested in hot peppers, and that current students who evaluate their professors are influenced by their attractiveness.

RMP can be a useful website for students. They can get a feel for what the professor is like before walking into the classroom. However, the information provided is not as reliable as many students may think. Students can make multiple submissions, either on purpose or by accident. Students may forget whether they have evaluated a professor and may make double remarks, while others may try to lift up or bring down a professor's ratings by commenting twice.

Also, bogus comments are possible since professors can rate themselves and their colleagues (Montell, 2006). Since students do not need to have a login ID to rate a professor, it makes it difficult to track who made which comment and it is therefore subject to a number of different types of abuse. However, not requiring an e-mail address allows students to make comments anonymously without having to worry about a professor or other students who read their comments. It is not likely that professors regularly make their own comments, or make comments on their colleagues' sites, but it is possible that it happens without anyone's awareness. In general, it can be abused in many different ways, even just to be funny. While the results can be frank and sincere, they are not necessarily representative of those who have actually taken the course.

Further problems result when, just like with student opinion forms, students tend to vent without providing useful information about the course or the professor. If a student is very pleased with the professor's teaching or very angry at the professor, he or she is more likely to make a comment on RMP than someone who had an average experience (Davison, 2006).

RMP evaluations are eventually reduced to the expression on a cartoon face and, possibly, a hot pepper. While browsing the names of faculty, if a student comes across a blue frowny face, he or she has a certain expectation of a poor professor before reading any comments. Similarly, a yellow smiley face or a hot pepper may immediately create a positive impression. In either case, it is difficult for the student to be objective when reading the comments that follow.

The biggest draw back of RMP is that it does not provide a statistically valid or representative sample of students (Cooladarci \& Kornfield, 2007). For example, one of the authors of this paper (JF) has taught over 700 students over the past three years. During this time only 21 postings have been made on RMP. In addition, only students who feel compelled to post on RMP are represented. So the students who respond on RMP are not only a small sample, but they are also a skewed sample.

While RMP can seemingly be useful to students, 84\% of students at Appalachian State University in 2004 found it helpful (Davison, 2006) it is not adequate to prepare students' expectations prior to coming into the classroom. It does not help the students to prepare to learn the subject matter. Universities need to help their students adjust their expectations and not allow RMP become students' only resource prior to coming into the classroom.

\section{TRADITIONAL STUDENT TEACHING EVALUATIONS}

Student evaluations of their university classroom experience have been conducted and the subject of academic studies since at least the 1920's (Remmers, 1927). "No method of evaluating college teaching has been researched more than student evaluations, with well over 2,000 studies referenced in the ERIC system. The preponderance of these study results has been positive, concluding that the evaluations are: (a) reliable and stable; (b) valid when compared with student learning and other indicators of effective teaching; (c) multidimensional in 
terms of what they assess; (d) useful in improving teaching; and (e) only minimally affected by various course, teacher, or student characteristics that could bias results (Centra, 2003)."

Many studies (cf. Hobson and Talbot, 2001; Cooladarci, T. \& Kornfield, 2007 and references contained therein) reviewed research on the reliability and validity of student evaluations and concluded that "well-developed student evaluations with adequate reliability and validity data may provide some of the best measures of teaching effectiveness." In spite of this research, it is not uncommon to find students who doubt value of these university administered evaluations (Ahmadi et al., 2001). Similarly, many faculty doubt the ability of these instruments to measure their teaching.

The primary audiences for the student evaluations are the professor, deans and personnel committees. Ideally, instructors will use this feedback to improve their instruction and the courses they teach. And the hope is that those evaluating faculty for promotion and tenure will carefully examine all aspects of these surveys and be aware of research that support their validity. However, students may only fill out the multiple choice section of the evaluation and skip the more revealing essay portion. Furthermore, while the written comments are given to the instructor, it is common for chairs, deans and personnel committees to receive only summaries of the responses to the multiple choice questions. As a result, the evaluations are frequently reduced to one or a few numbers that attempt to average all the multiple choice responses. This is similar to the RMP web site which uses hot peppers, smiley and frowny faces to summarize a professor's evaluation.

RMP is designed for a student audience; university administered evaluations of teaching are not. There is a wealth of research on the reliability and validity of traditional teaching evaluation; there are many recent publications that focus on the flaws of RMP. The logical question is: Why not make universities developed and administered student teaching evaluations available to the students?

Although some colleges now make such information publicly available, many more still do not (Kindred and Mohammed 2005). Central Michigan University is one of the few to permit students to access student opinion surveys. However, the availability of the evaluations is not well-known, obtaining the material is not convenient, and not all information is shared with the students. An informal poll of over a hundred students of one of the authors of this paper (JF) revealed that none of them knew they were permitted access to student opinion surveys. Even if they were aware of this, the students would have discovered that the information must be checked out from the reserve desk at the library. After signing a check-out form, the students would be given a cd and instructed to search for a professor of interest. The information they would eventually access is the same that is available to the deans: no written student comments and average scores on the multiple choice questions. Students have always had a desire for information about their potential classes and instructors. Today's students are accustomed to accessing information immediately and with ease. This combination assures continued use of internet sites like RMP.

\section{THE PHYSICS CLASS IN THIS STUDY}

Like almost all other universities, Central Michigan offers a full-year introductory algebra based course that is a significant department service course. The students in College Physics I and II are the subjects of this study. In the winter semester over 180 students are enrolled in two sections of College Physics I. In the following fall semester, 120 students are enrolled in one section of College Physics II. The profile of these CMU physics students is displayed in Table 1 and is similar to what one might find in a college physics course at many universities.

On the first day of class the syllabus (see Table 2) is distributed, presented and students are given ample time to ask questions regarding all course policies. This syllabus contains all the standard information as suggested by Altman,1989; Birdsall, 1989; Lowther et al., 1989; Wilkerson and McKnight, 1978. In addition, there is a "Final Words" section which gives tips and encouragement for the students to succeed in the physics class. Included are recommendations to work together, to not procrastinate in homework, and do not be afraid to ask for help from the professor and physics tutors. For twenty-eight years the professor (JF) has wondered what the students absorb this first day. 


\begin{tabular}{|c|c|c|c|c|}
\hline CLASS & $36 \%$ Seniors & $\begin{array}{c}29 \% \\
\text { Juniors }\end{array}$ & $\begin{array}{c}26 \% \\
\text { Sophomores } \\
\end{array}$ & $\begin{array}{c}10 \% \\
\text { Freshmen }\end{array}$ \\
\hline MAJOR & $34 \%$ Health Fields & $\begin{array}{c}27 \% \\
\text { Biology }\end{array}$ & $\begin{array}{c}18 \% \text { Industrial } \\
\text { Technology }\end{array}$ & $8 \%$ Physical Sciences \\
\hline MATH LEVEL & $22 \%$ Algebra & $\begin{array}{c}36 \% \\
\text { Pre-calculus }\end{array}$ & $42 \%$ Calculus & \\
\hline HS PHYSICS & $\begin{array}{r}67 \% \\
\text { Yes } \\
\end{array}$ & $\begin{array}{c}33 \% \\
\text { No }\end{array}$ & & \\
\hline GENDER & $\begin{array}{c}51 \% \\
\text { Female }\end{array}$ & $\begin{array}{l}49 \% \\
\text { Male }\end{array}$ & & \\
\hline MEAN GPA & 3.1 & & & \\
\hline
\end{tabular}

\begin{tabular}{|l|l|}
\hline \multicolumn{2}{|c|}{ Table 2: Contents of the college physics syllabus. } \\
\hline CONTACT INFORMATION & Instructor contact information and office hours \\
\hline INTRODUCTION & Material covered in the course and suitability of the course for various majors \\
\hline TEXT & Text available from the bookstore, and sample exams available on blackboard \\
\hline HOMEWORK & Homework policy and instructions for using the web to submit homework answers \\
\hline EXAMS & Exam dates, makeup policy, and difficulty \\
\hline PAST GRADES & Summary of grades given in the past two years \\
\hline HELP ROOM AND TUTORS & Physics help room hours and availability of tutors \\
\hline FINAL WORDS & Tips for success \\
\hline ACCOMODATIONS & University policy for accommodating students with disabilities \\
\hline CALENDAR & $\begin{array}{l}\text { Calendar with material that is planned to be covered each day, homework due dates, and } \\
\text { exam dates }\end{array}$ \\
\hline
\end{tabular}

\section{ADVICE FROM EXPERIENCED STUDENTS TO NEWCOMERS}

At the end of second semester of College Physics II (PHY 131), one of the authors (JF) has added an additional question to the essay portion of the student evaluation form. It asks, "What advice would you give to students taking College Physics I (PHY 130) next semester?" After grades are submitted all the written responses to the student opinion survey are given to the faculty member. Over ninety-percent of the students voluntarily provide this advice. For the last three years the response to this additional question have been compiled and the week before the start of the upcoming semester, this advice is passed on to the students who are about to begin their physics education in college.

The vehicles used to pass on this advice are BlackBoard ${ }^{\mathrm{TM}}$ and the World Wide Web. At Central Michigan University students start to enroll in October for the semester beginning in January. From the start of this enrollment process, faculty have access to their class lists. So all the advice written in December by the College Physics II class is distributed to the College Physics I class during the first week of January via BlackBoard ${ }^{\mathrm{TM}}$. In addition, this is an opportunity to send the students a message of welcome from the professor, which points them to an online syllabus (so they see policies and organization before they come to their first class).

Limited editing is done to the advice that is passed from the experienced class to the incoming class. No editing is done to poor grammar, and misspellings are never corrected. However, any profane remarks are replaced with characters such as $\$^{\wedge} \# \%$ and no names of students of any other faculty make it into the final copy. Finally, almost all physics lectures always are accompanied by demonstrations. There are a number of students that give general advice, such as, "Watch out for flying objects," but anything more specific could ruin the drama, element of surprise or the purpose of the demonstration. Such remarks that give away secrets of demonstrations are deleted. Usually, only a few comments need editing and the future students receive unfiltered and sincere comments from their predecessors. 
Table 3 gives the most common comments made by the college physics students in response to the "give future students advice" question and in RMP. The distinction is that in the first case the students are clearly speaking to future students and giving them advice on how to succeed, while RMP comments focus on the good and bad qualities of the teacher and how to get by with the least amount of effort.

It is important to recognize the number of students who participate in the three different teacher evaluation formats discussed in this paper. For the university administered student opinion surveys the maximum number of responses is determined primarily by the attendance on the day the evaluations are conducted. For the three classes examined here the attendance and response rate was 70-80 percent. For two of the classes ninety-percent of these students also submitted advice to future students, and for the 2004 class, every student who filled out a student opinion survey provided advice. Indeed, for all three classes more students responded to the "advice" question than responded to the three other "essay" questions on the student opinion survey. By comparison, over the same three years fewer than three percent of these same students elected to post a comment on RateMyProfessors.com.

\begin{tabular}{|l|l|}
\hline \multicolumn{2}{|c|}{ Table 3: Sample comments from past students giving advice and RMP remarks } \\
\hline Advice from past students & RMP Comments \\
\hline "Do all of the homework!" & "He's a good teacher and entertaining." \\
\hline $\begin{array}{l}\text { "Start your homework as soon as you can! Do a couple of } \\
\text { questions a day..." }\end{array}$ & "The class is very tough, but he makes it as easy as possible." \\
\hline "Going to class is very beneficial." & "He makes physics fun and interesting." \\
\hline $\begin{array}{l}\text { "Do practice exams before the class where you go over } \\
\text { them." }\end{array}$ & $\begin{array}{l}\text { "He teaches you the concepts before giving you the } \\
\text { problems..." }\end{array}$ \\
\hline $\begin{array}{l}\text { "Make friends w/ people to do homework with - you'll need } \\
\text { each other." }\end{array}$ & "Do the practice exams and go to class and you'll do fine." \\
\hline "Form a study group!" & "Yes, he's a nice guy who plays music before class." \\
\hline "If you have any questions go to office hours." & "Do not miss a class and you'll do fine." \\
\hline
\end{tabular}

Table 4 displays a summary of the most frequent comments made by the students. One must be impressed with these students. The most common advice they give is exactly what their professor would tell incoming students: do the homework and do it in advance of the deadlines; go to class every day; take advantage of the sample exams provided; find study "buddies"; and make use of the professor's office hours and help room services. The only ambiguous advice that appears year after year regards the textbook. This reaction to a textbook is probably not surprising to any faculty member.

\begin{tabular}{|c|c|c|c|c|}
\hline Advice & $2004(\mathrm{~N}=68)$ & $2005(\mathrm{~N}=67)$ & $2006(\mathrm{~N}=56)$ & Total $(\mathrm{N}=191)$ \\
\hline Do all of the homework & 20 & 31 & 38 & 89 \\
\hline Do not procrastinate with homework & 27 & 30 & 25 & 82 \\
\hline Go to class every day & 17 & 34 & 26 & 77 \\
\hline Do practice/sample exams & 20 & 28 & 27 & 75 \\
\hline Make a study friend(s) & 18 & 13 & 5 & 36 \\
\hline Use the tutors* & 5 & 11 & 16 & 32 \\
\hline Go to office hours & 7 & 10 & 10 & 27 \\
\hline Ask questions; ask for help (general) & 5 & 8 & 3 & 16 \\
\hline Don't buy the book & 3 & 6 & 5 & 14 \\
\hline Read/use the book & 2 & 2 & 2 & 6 \\
\hline
\end{tabular}


Table 5 lists some of the more lighthearted comments made by the students. The incoming students enjoy these and it helps gives them a reason to keep reading all the 60-70 pieces of advice. Foreshadowing is evident here and it make the students wonder what is going to happen in this class (i.e.: Why do I need a helmet? What is with the garbage can? There is music in a physics class? Are the demonstrations dangerous or dorky?). Most importantly, it helps ease the fears students who are frightened about taking a physics class. They see that their peers not only survived the class, but also seemed to have an enjoyable experience.

Table 5: Lighthearted comments made by students when they give advice

"Make sure you wear a U of M Hoodie to class every day. Also, make sure to have a U of M coffee mug and lots of other stuff. It will help your grade a lot. Oh, and start Capa before Sunday."

"Finally, invest in a helmet."

"Buy a two or three subject notebook and use it ONLY for this class."

"Go to class so you have the notes and if you miss class make sure you get the notes you missed... everyday is basically a vital day! Relax \& have fun... enjoy the music \& sometimes dorky examples because it makes the class pretty fun:)"

"Learn to appreciate the demonstration value of a garbage can; it is a powerful teaching manipulative."

"Dr. Finck is great, go to his office hours (trust me the pictures will make sense eventually)."

"There is an unspoken rule, Do Not try any demonstrations @ home."

"Be ready for some cool demonstrations, exciting lectures, good music, and even a few new holidays you didn't even know existed."

"Cover your ears when he drops the trash can..... its LOUD! Oh... and watch out for flying projectiles!"

"Understand that people from the Upper Peninsula can do things you can't do. Relax."

"Do capa. Study old exams. Be happy."

Other teachers have used varying methods of experienced students giving advice to future students. There are a variety of websites where professors teaching classes from introductory to graduate level have provided such advice (Meyer, 2005; University of Washington, 2007; Yale University, 2007), and some websites have even suggested it for elementary school lesson plans (Connell, 2007; Nash, 2007). Felder and Brent (1995) discuss how to start the first day well. They suggest to "Do something to motivate the student's interest," and under this category they recommend to try this method: "Share advice from previous students collected at the end of the last course offering."

Another technique is to invite former students to speak with the students in new classes. At Central Michigan University the professor (Swanson, 2007) who teaches the honor section of Biology 101 invites two former students to the first day of class. After going through the syllabus, he leaves and the two experienced students respond to questions.

At Ohio State University it has become the practice of Statistics 135 to gather advice from students electronically. "Hundreds of testimonials are then placed online to help advise student learners in the following quarters (Microsoft, 2003)." Their program, called Statistical Buffet has been a revolutionary course that allows students to obtain instruction in a way that reflects their learning style. Since it is such a new program and is rarely used elsewhere, incoming students may want to find out more information from previous students regarding the procedure and what their thoughts were on the course. The students themselves testify that receiving this advice was beneficial to them in the course. 


\section{CONCLUSIONS AND SUGGESTIONS FOR FURTHER STUDIES}

Before class begins students will look at RMP and talk to peers who have taken the class or professor, and wonder if the advice can be trusted. On the first day of class the professor will distribute the syllabus, answer questions about the class, encourage them to work hard, and wonder if the students are paying attention to anything he or she is saying. It would clearly be valuable to students to receive advice from many peers who have taken this class from this professor, and to have this information available before the first day of class.

This paper illustrates that students who have taken a class for one or two semesters from a professor can offer valuable information to their subsequent classmates. Further, utilizing classroom management tools such as BlackBoard.com ${ }^{\mathrm{TM}}$, it is easy for the professor to pass this advice to his incoming class. Unlike university administered student evaluations of their teachers, the audience described in this study is future students. In addition, since the sample size is large and the student's comments are directed to a subsequent class, the advice is much more reliable than what is available on websites such as RateMyProfessor.com.

Further studies have already been initiated. Data has just been collected from the college physics classes at Talahassee Community College and Lyman Briggs College at Michigan State University. While the physics students will be examined as in the current study, the student profiles are very different. Talahassee Community College has an open enrollment policy. Some students are attracted because of the cost or convenience, but others are there to prove that they can be successful at college. Lyman Briggs College is a residential college focusing on the study of science and its impact on society. It offers the benefits of a small, liberal arts college with the resources of a major research university. Additionally, the authors of this paper will attempt to identify non-physics and nonscience faculty who would be interested in utilizing a similar tactic in their classes.

Finally, there are two important questions about forwarding advice from experienced students onto an incoming class. First, do the students read the advice that is sent to them before class starts? Second, do they take this advice seriously? The authors of this paper plan to address both of these issues in the spring semester of 2008. Two weeks into this semester, the students will be asked if they read the advice from previous students. Then two weeks before the end of the semester, these same students will be asked if they heeded this advice.

\section{REFERENCES}

1. (Howard, J. A.) In Miller, T. E., Bender, B. E., Schuh, J. H., and associates. (2005a). Why Should We Care About Student Expectations? Promoting Reasonable Expectations, San Francisco, CA:Jossey-Bass Publishers. 22.

2. (Knefelkamp,L.) In Rubin, S. Professors, Students, and the Syllabus, The Chronicle of Higher Education, August 7,1985, 85.

3. (Kuh, G. D., Gonyea, R. M., and Williams, J. M.) In Miller, T. E., Bender, B. E., Schuh, J. H., and associates. (2005b). What Students Expect from College and What They Get, Promoting Reasonable Expectations, San Francisco, CA:Jossey-Bass Publishers. 35.

4. Ahmadi, M., Helms, M. M., \& Raiszadeh, F. (2001). Business students' perceptions of faculty evaluations. The International Journal of Educational Management, 15 (1), 12-22.

5. $\quad$ Altman H. B., Cashin, W. E. (1989) Writing a Syllabus.” Retrieved from (http://honolulu.hawaii.edu/intranet/committees/FacDevCom/guidebk/teachtip/writesyl.htm).

6. Altman, H.B. Syllabus shares, What the Teacher Wants. The Teaching Professor, May 1989, 3, 1-2.

7. Birdsall, M., Writing, Designing, and Using a Course Syllabus. Boston: Northeastern University, Office of Instructional Development and Evaluation, 1989.

8. Boice, R., Advice for New Faculty Members Nihil Nimus. Boston: Allyn and Bacon, 2000.

9. Campbell, H. E., Gerdes, K., and Steiner, S., What's looks got to do with it? Instructor appearance and student evaluations of teaching. Journal of Policy Analysis and Management, 2005, 24(3), 611-620.

10. Centra, J. A. (2003). Will teachers receive higher student evaluations by giving higher grades and less course work? Research in Higher Education, 44, 496-518. 
11. Connell, G. Let Me Give You a Little Advice. Scholastic, Inc. Retrieved December 4, 2007 from (http://content.scholastic.com/browse/lessonplan.jsp?id=65).

12. Cooladarci, T., and Kornfield, I. RateMyProfessors.com versus formal in-class evaluations of teaching. Practical Assessment, Research \& Evaluation, 2007, 12(6), 1-13.

13. Davis, B. G., Tools for Teaching. Jossey-Bass Publishers: San Francisco, 2006.

14. Davison, E. and Price, J. How Do We Rate? An Evaluation of Online Student Evaluations. Department of Sociology and Social Work, Appalachian State University, August 2006. This article may be retrieved via the following URL: (http://www1.appstate.edu/ pricej1/TEACHING/methods/RMP_8_06.pdf).

15. Dberly, M. B., Newton, S. E. and Wiggins, R. A. The Syllabus as a Tool for Student-Centered Learning. The Journal of General Education, 2001, 50(1), 56-74.

16. Eberly, M. B., Newton, S. E., and Wiggins, R. A. The syllabus as a Tool for Student-Centered Learning. The Journal of General Education, 2001,50 (1), 56-74.

17. Feeley, T. H. (2002). Evidence of halo effects in student evaluations of instruction. Communication Education, 51 (3), 225-236.

18. Felder, R. M., and Brent. R. (1995) Getting Started. Chem. Engr. Education. 29(3), pp166-167. This article may be retrieved via the following URL: (http://www4.ncsu.edu/unity/lockers/users/f/felder/public/Columns/Getstart.html).

19. Felder, R. M., and Brent, R. How to Prepare New Courses While Keeping Your Sanity. Chem. Engr. Education, 2007, 41(2), 131-122.

20. Felton, J., Mitchell, J., and Stinson, M. Web-based student evaluation of professors: the relations between perceived quality, easiness and sexiness. Assessment and Evaluation in Higher Education, 2004, 29(1), 91108.

21. Hobson, S. M., and Talbot, D. M. Understanding Student Evaluations. College teaching, 2001, 49(1), 2631 .

22. Kindred, J. \& Mohammed, S. N. (2005). He will crush you like an academic Ninja!: Exploring teacher ratings on Ratemyprofessors.com. Journal of Computer-Mediated Communication, 10(3).

23. Lowther, M. A., Stark, J. S., and Martens, G.G., Preparing Course Syllabi for Improved Communication. Ann Arbor: University of Michigan, National Center for Research to Improve Post-secondary Teaching and Learning, 1989.

24. McKeachie, W. J. (2006). Teaching Tips. 12 th Ed. Boston: Houghton Mifflin Company.

25. McKeachie, W. J. and Gibbs, G. (2001). Teaching Tips: Strategies, Research, and Theory for College and University Teachers, 11 th ed. Boston: Houghton Mifflin Company.

26. Meyer, J. L. Department of Entomology. NC State. General Entomology ENT 425 Free Advice from Former Students. Last Modified: April 20, 2005. Retrieved Dec 4, 2007 from (http://www.cals.ncsu.edu/course/ent425/advice.html).

27. Microsoft. A search for new heroes. Computerworld Honors, 2003, Retrieved November 28, 2007 from the following URL: (http://www.cwhonors.org/search/his_4a_detail.asp?id=4826).

28. Montell, G. A. The art of the bogus rating. The Chronicle of Higher Education, September 27, 2006. Retrieved November 22, 2006, from (http://chronicle.com/jobs/news/2006/09/2006092701c/careers.html).

29. Nash, L. Friendly letters giving advice on getthing thru the year. The Lesson Plans Page. Retrieved Dec 4, 2007 from (http://www.lessonplanspage.com/LAWritingLettersAtEndOfYearForStudentsNextYear48.htm).

30. Nasser, F., \& Fresko, B.

31. Otto, J., Sanford, D. A., and Ross, D. N., Dose ratemyprofessor.com really rate my professor? Assessment \& Evaluation in Higher Education, 2008, 33(1), 1-16.

32. RateMyProfessors.com, 2007. Retrieved June 2, 2007 from the following URL: (ratemyprofessors.com/About.jsp).

33. RateMyProfessors.com, 2007. Retrieved November 28, 2007 from the following URL: (ratemyprofessors.com).

34. Remmers, H. H. The Purdue Rating Scale for Instructors. Educational Administration and Supervision, 1927, 6, 399-406.

35. Swanson, B., Central Michigan University, private communication, 2007. 
36. UCSD Profesor, 2007. Retrieved November 28, 2007 from the following URL:

(http://project.ucsd.edu/professor/).

37. University of Washington. MEDCH 451 - Medicinal Biochemistry II. Last modified: March 22, 2007. Retrieved Dec 4, 2007 from (http://depts.washington.edu/medchem/courses_451_advice.html).

38. Wilkerson, L., \& McKnight, R.T. (1978). Writing a Course Syllabus: A Self-Study Packet for College Teachers. Chicago: Michael Reese Hospital and Medical Center.

39. Wright, D. L. The Most Important Day: Starting Well. Teaching at UNL, 1989, 7(1).

40. Yale University. Advice from Previous Chem 125 Students. Retrieved Dec 4, 2007 from (http://www.chem.yale.edu/ chem125/125/Help/studentadvice00.htm).

41. Zakrajsek, T., Central Michigan University, private communication, 2007. 
NOTES 